\title{
Gyms Coverage in the City of Manizales and Villamaría Through Accessibility Analysis by the Pedestrian Network Infrastructure
}

\author{
Diego A. Escobar ${ }^{1}$, Carlos A. Moncada ${ }^{2} \&$ Sergio Idarraga $^{1}$ \\ ${ }^{1}$ Universidad Nacional de Colombia, Sede Manizales. Facultad de Ingeniería y Arquitectura, Departamento de \\ Ingeniería Civil, Carrera 27 \# 64-60, Manizales, 170004, Colombia \\ ${ }^{2}$ Universidad Nacional de Colombia, Sede Bogotá. Facultad de Ingeniería, Departamento de Ingeniería Civil y \\ Agrícola, Ciudad Universitaria edificio 214 oficina 417, Bogotá, 111321, Colombia \\ Correspondence: Diego A. Escobar, Universidad Nacional de Colombia, Sede Manizales. Facultad de Ingeniería \\ y Arquitectura, Departamento de Ingeniería Civil, Carrera 27 \# 64-60, Manizales, 170004, Colombia. E-mail: \\ daescobarga@unal.edu.co/camoncadaa@unal.edu.co/camoncadaa@unal.edu.co
}

Received: August 1, 2018

Accepted: August 14, 2018

Online Published: August 27, 2018

doi:10.5539/mas.v12n9p180

URL: https://doi.org/10.5539/mas.v12n9p180

The research is financed by Universidad Nacional de Colombia, Facultad de Ingeniería y Arquitectura.

\begin{abstract}
Taking into account that Colombia has $1 \%$ of the established gymnasiums in the world and that Manizales and Villamaría own 45 of these establishments, it is sought to relate the reason for the high percentage of sedentary lifestyles in Colombia (60\%) and determine which degree of coverage has the area of study in regard to these establishments. Through this research, we seek to evaluate the relationship between the spatial coverage of gyms in the city of Manizales and Villamaría and their relationship with sedentary lifestyles and the high dropout rates that occur in them. Through an analysis of integral accessibility, by means of the city's pedestrian network, the isochronous coverage curves of the gyms are constructed using the travel time of the pedestrian network nodes to the nearest gymnasium and the geo-statistical model Ordinary Kriging. Finally, inequality is found according to the socioeconomic stratification because low-income people have less coverage of these establishments.
\end{abstract}

Keywords: Gyms, integral accessibility, sedentary lifestyle, physical activity, walking, coverage

\section{Introduction}

"The term physical activity refers to any body movement produced by the skeletal muscles and that results in an energy spending that is added to the basal metabolism" (Varo, Martínez \& González, 2003, p.33). Over the years the physical activity term has been developed and extended, being covered by an infinity of sports or types of training that stimulate different parts of the body, which have gained popularity during the last decade due to the nascent trend of healthy life that has adopted much of the population, either for aesthetic reasons or for simple care and welfare. However, the opposite of this trend is found in sedentary lifestyle, which according to the World Health Organization (WHO) (2002), is one of the 10 leading indicators of mortality and disability around the world, causing $6 \%$ of the deaths, thus becoming declared a public health problem. Therefore, it is considered sedentary lifestyle or lack of physical activity if the person does not make any movement that generates a caloric spending greater than $10 \%$ of what would generate a daily activity, with a minimum of 25 to 30 minutes a day (Varela, Duarte, Salazar, Lema, \& Tamayo, 2011).

Globally, sedentary lifestyle prevails in $17 \%$ of the population, and in Colombia, according to the National Survey of Nutritional Situation, periodically carried out by the Ministry of Health, as cited by Varela et al. (2011), percentages are reached up to $58 \%$, quite high figures taking into account the global value, reaching higher percentages of sedentary lifestyle in men than in women. It is so much like this, that only in 2005, there were around 170000 deaths in Latin America due to complications derived from sedentary lifestyles (Pan-American Health Organization [OPS for its acronym in spanish], 2006). That being said, it is important to clarify that it is a difficult problem to control because, despite the efforts of the WHO and different local health institutions present in different continents to promote physical activity, sports and healthy life through creation of commemorative days and events that are driven by it, the sedentary lifestyle grows exponentially. Thus, this growth is occurring, 
in large part, due to the passivity within which different jobs that may exist today, as well as current leisure activities, which although not requiring any type of physical effort or energy spending, consume most of a person's day, leaving aside the possibility of doing some type of exercise (Varo, Martínez, \& González, 2003). It is clear that a sedentary life itself is not a cause of death in any person, the problem lies in that it derives endless diseases, in the case of not making a drastic change of habits, can lead to death, and some of them are: Cardiovascular diseases such as hypertension, ischemic heart disease, cerebrovascular accidents, obesity in children and adults, diabetes, osteoporosis or joint weakness, mental illness, cancer risk, among others (Varo et al., 2003). Taking into account the above, it is important to mention that one of the main players in the fight against sedentary lifestyle are gyms which at the same time represent the most popular option for most people when it comes to physical activity. Although such places are the most popular option today, and each day new people acquire the motivation to start changes in their lives through this medium, the large proportion of desertion that is witnesses daily in gyms due to different factors that discourage the continuity is undeniable. It is so much like that, that in a study conducted at a local level it was established that $88 \%$ of the people interrupt their continuity in such establishments, without reaching any of the initially proposed objectives (Franco, A. M. Ayala, \& J. E. Ayala, 2011).

There are many reasons, mostly psychical, by which this amount of desertion is generated, all originated by external factors. One of these factors, as mentioned above, is the limited availability of time that a person has, especially if they must invest a large amount of time just to get to the training center; that is why the accessibility that someone can have to the different gyms plays a key role when it comes to maintaining continuity and being constant in the realization of physical activity. This concept has been developed and expanded over the years, being defined by a myriad of authors who infuse in such paraphrasing their vision about accessibility, keeping mostly one aspect in common, consider the concept of G. Walter Hansen as one of its bases. Thus, it is known as accessibility, according to Hansen (1959), to the potential of opportunities to perform an interaction of an inhabitant of a given region, as well as the distribution of activities that occur around a point. Similarly, it is considered as the ease with which you can get to an equipment, such as gyms, starting from a place and making use of a specific transport system (Morris, Dumble, \& Wigan, 1979). On the other hand, Geurs and Ritsema van Eck (2003) defined the concept of accessibility as measurements that described the service level of a road infrastructure network, based on a study of how accessibility affected land use in the Netherlands. In addition to the above, terms such as relative accessibility were developed; this refers to the degree of connection that have two points to each other, both located on the same surface and road network, with the exemption that the intensity of such points will not be the same, and it will vary depending on the direction in which the analysis is carried out (Ingram, 1971); integral accessibility, basically deals with the characteristics of interconnection that may exist between a point and the rest of its peers through the road network (Ingram, 1971), and which has been used in the study of accessibility to places that provide specific services such as schools (Zuluaga, Escobar, \& Hincapié, 2017), universities (Younes, Escobar, \& Holguín, 2016), hospitals (Rodríguez Díaz, 2011) and the diverse primary activity nodes (Escobar, Cadena, \& Salas, 2016), among others.

In this way, as in previous investigations that have managed to establish a relationship and finally a solution between accessibility and different mobility problems that may arise (Moncada, Cardona, \& Escobar, 2018; Montoya, Escobar, \& Zuluaga, 2017; Perilla, Escobar, \& Cardona, 2018), the investigative process was carried out in order to establish the existing relationship between the integral accessibility to the gyms (red dots in figure 1), through the pedestrian infrastructure network of the city, and the different life complications that may generate a sedentary lifestyle, all in the capital of the department of Caldas, Manizales (see figure 1), and in Villamaría, a municipality adjacent to it. Located within the well-known coffee triangle, in the Andean region, in the center west of Colombia, between both municipalities have a total of 419689 inhabitants projected for the year 2017 according to the National Administrative Department of Statistics -DANE- (DANE, 2010) and an urban area of 5863 hectares, that is, they have a population density of 72 people per hectare. Manizales has an average height of 2150 masl and an average temperature of $18^{\circ} \mathrm{C}$ (ATEC, 2015), which varies as the city is crossed due to its abrupt topography. In addition, the municipality of Villamaría has an average height of 1920 meters, as well as a temperature of $18^{\circ}$ C (ATEC, 2015). Although in both municipalities there are quite considerable slope changes from one point to another, its small extension means that a large number of inhabitants (29\%) choose walking as a preferred means of transport, as well as $24 \%$ of the population prefer public transportation, and finally $25 \%$ the private vehicle (Alcaldía de Manizales, 2017). Although practically all the gyms are constituted as private spaces independent from the state, it is important to mention that through the work done gradually by the City Hall of Manizales and the Sports Secretariat, it is about busting and encouraging the practice of sport and the acquisition of healthy habits in children and adults, all through activities such as intercollegiate local games (Gobierno de Caldas, 2018), tournaments in the different disciplines or the provision of the space of the 'ciclovía' (e.i. cycle-rout), in which every Sunday a section of Santander Avenue, one of the city's main avenues, is temporarily closed, so that only 
pedestrians and cyclists have access to it (Secretaría del Deporte Alcaldía de Manizales, 2015). On the other hand, both in Manizales and in Villamaría, as well as in all of Colombia, since 1991 a classification of the different zones of a city has been made in socioeconomic terms, according to the social stratification system, which allows orienting the planning of the public investment (DANE, 2018). Among other things, it measures the economic capacity of the inhabitants to, according to this, make the collection of different public services, with stratum 1 being the lowest capacity, and stratum 6 with the highest capacity (DANE, 2018).

After the introduction, the methodology used in the research is presented and the main results are listed, and finally, the conclusions reached through the study.

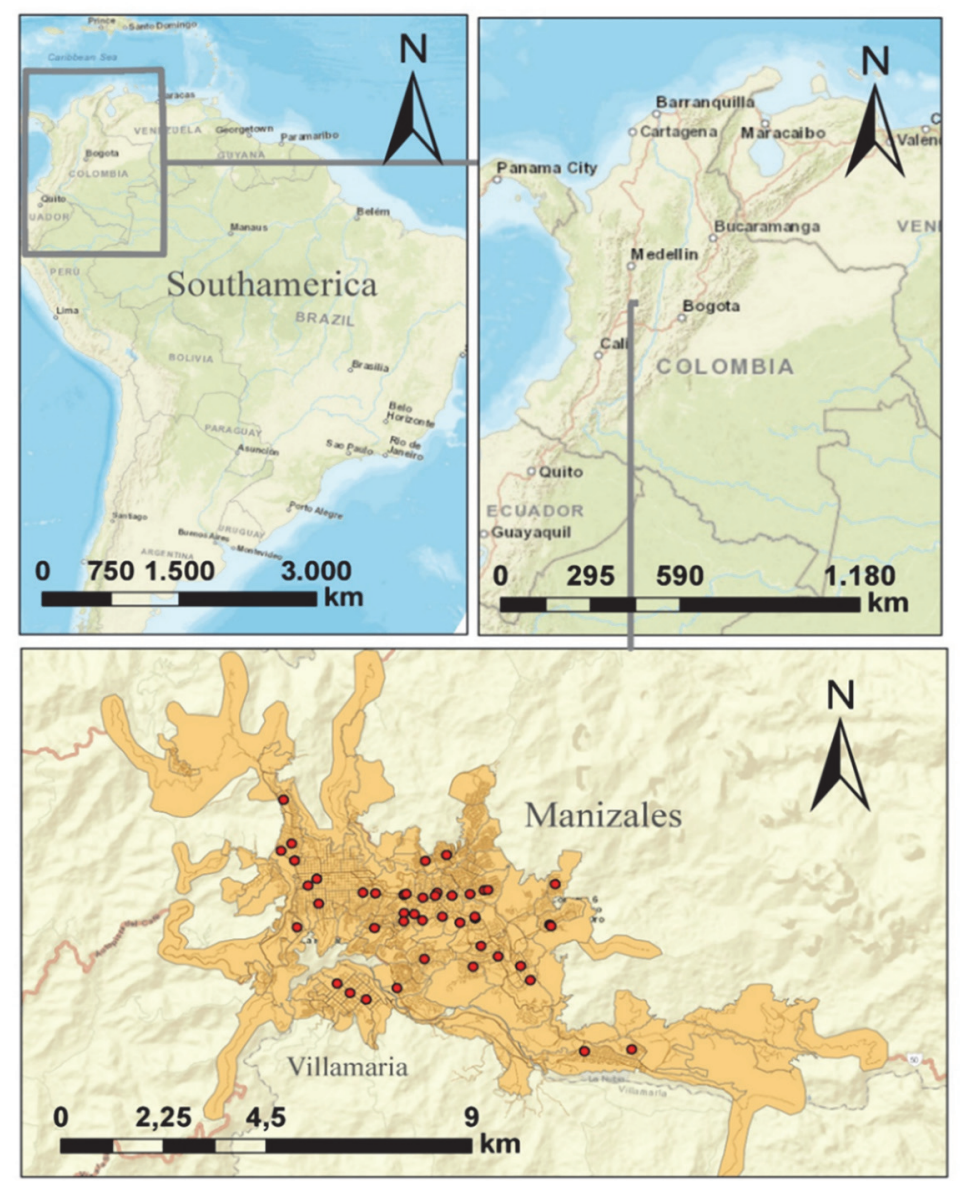

Figure 1. Geographical location of Manizales and Villamaría

Source: Self-made.

\section{Methodology}

The applied research methodology was developed in 3 different stages, which will be described in figure 2 .

\subsection{Obtaining and applying databases and information}

During this stage, the respective location and georeferencing of the different gyms existing in the municipalities of Manizales and Villamaría was made, all through the geographic information system GIS and supported by the database provided by the Chamber of Commerce of the region. (Chamber of Commerce of Manizales by Caldas, 2018). It is important to clarify that, despite being an official source, it is possible that such information does not contain all the gyms or training centers established in both municipalities, since some of them may not be duly registered in the governing body or have a social name that does not determine physical activity as its main function. Similarly, through the use of previous studies and research (Escobar \& García, 2012; Perilla et al., 2018), the road and pedestrian network of both municipalities was complemented by the construction of pedestrian links that would describe the different routes that were possible to take by any average pedestrian, referring to spaces such as: streets determined for purely pedestrian use, stairs between different neighborhoods, pedestrian bridges, etc. 


\subsection{Calculation of Integral Accessibility}

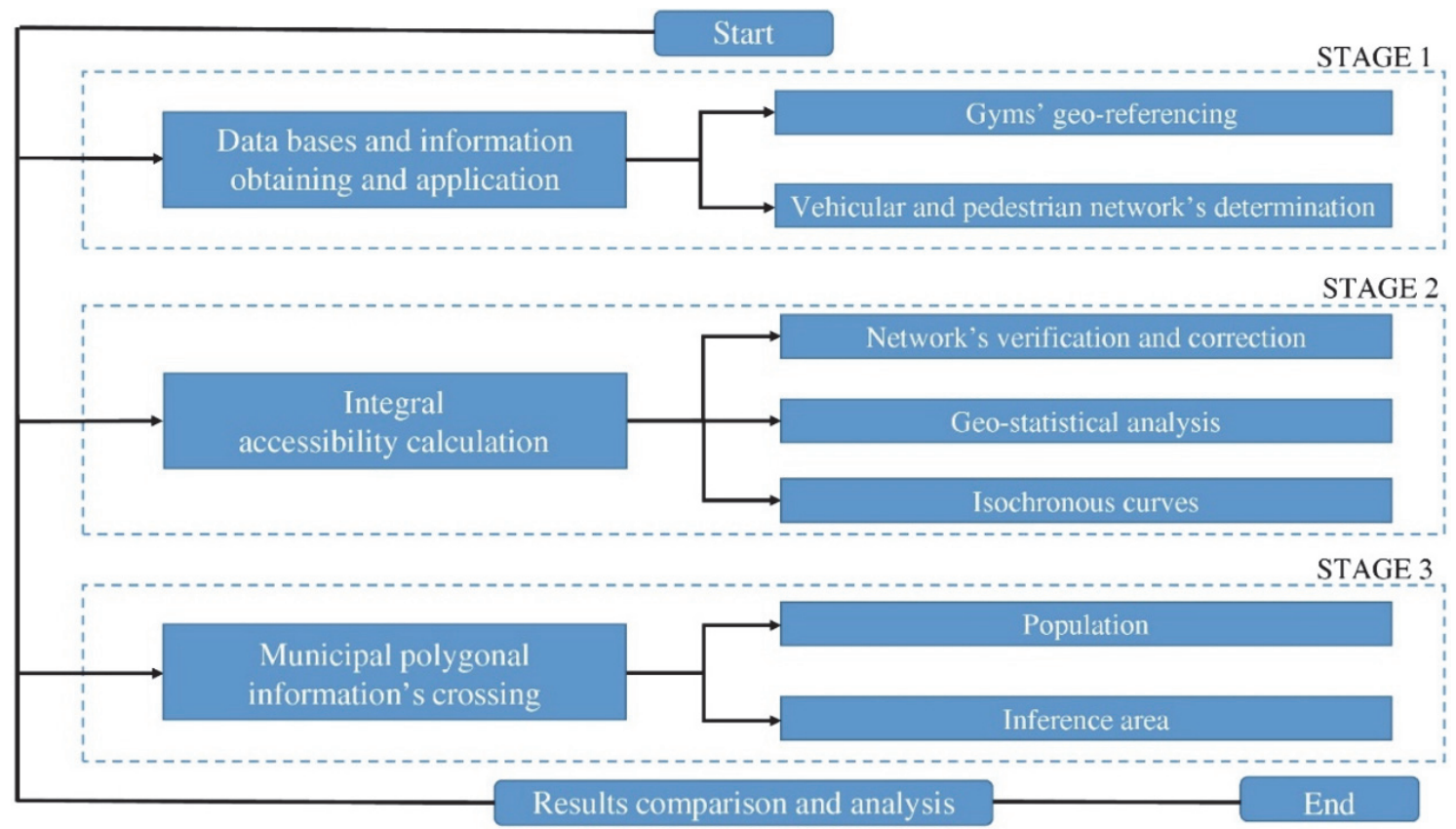

Figure 2. Research methodology

Source: Self-made.

Initially, using different tools contained in ArcGis, GIS software, the topology of the network was corrected, verifying that all the links plotted coincided with the reality of the road and pedestrian infrastructure (Kozyrev, 1972). After that, the lengths of each of the arcs that make up the network were calculated and, as a last step to be developed in such software, the calculation of travel times for each arc was made, all through the use from equation 1. It should be clarified that for the above, it was taken into account that, during an investigation carried out in Manizales, it was determined that the average speed of a pedestrian is $4.32 \mathrm{~km} / \mathrm{h}$ (Montoya, Escobar, \& Zuluaga, 2017); thus, this value, together with the lengths of arcs previously calculated, allowed obtaining the travel times by arc.

$$
T v i=\frac{\text { Arc Length }}{\text { Pedestrian Speed }}
$$

However, with the attributes of the complete pedestrian network, an entry was made to an additional geographic information system that has a specific transport modeling analysis package, TRANSCAD, seeking to find the minimum travel time vectors. Through it, as an initial step, it was necessary to specify, for each of the gyms, its closest node within the network, this in order to place them as reference points for the software at the time of running the procedure. Then, by using the algorithm of minimum paths, travel times were calculated from each node of the network, to the service node, which is, in this case, the closest to the gym node, from which the trips matrix is obtained with the optimal routes between the different analyzed points (Dijkstra, 1959). According to the results obtained by the travel matrix $(10312 \times 45)$, the minimum travel times are related to the respective geographic coordinates, obtaining the travel time of each node, to the nearest gym through the road network.

Thus, already in ArcGis, by using the vector of minimum travel times, the ordinary Kriging geo-statistical method is used for the construction of the isochrones curves of integral accessibility that allows observing the behavior of the offer of gyms on the municipalities under study. It is important to understand geostatistics as one of the branches of statistics that evaluates spatial phenomena and takes as its main objective its estimation, prediction and simulation (Giraldo, 2012). The Ordinary Kriging method, the most used at present when modeling issues related to transit and transportation (Escobar, Montoya, \& Moncada, 2018; Prasetiyowati, Imrona, Ummah, \& Sibaroni, 2016), which bases its procedures on the minimization of the mean square error of the prediction of the behavior of the variable to be analyzed, in this case of accessibility of zones where no data is available and assumes that such values can be predicted as a linear combination of $\mathrm{n}$ variables with data with available values, in this case the vector of travel times (Giraldo, 2012). That being said, each node will have a weighted weight, that is, it will use 
the minimum time it uses to reach the nearest service (Giraldo, 2012). Likewise, the model, within its calculations, develops a linear semivariogram, which seeks to characterize the properties of spatial dependence of the process (Giraldo 2012). Finally, through its application, the obtaining of the isochrones accessibility curves is achieved, proceeding with its extension and definition in the study area.

\subsection{Intersection with polygonal information of the municipalities}

For this final phase, it is necessary to include the polygon of the neighborhoods that make up the municipalities of Manizales and Villamaría, which contains information on the areas of extension, the population that occupy them, categorization by strata, among other factors. Prior to the intersection, it is important to clarify that the respective information to the population is registered for the year 2015, for which it is necessary to carry out a projection until 2017, based on the DANE population census conducted in 2005 (DANE, 2017). With these updated values, the polygon is intercepted with isochronous curves to determine the relationship between the isochronous curves, the population, coverage area and stratification, from which the conditions of each zone of the city can be analyzed independently.

\section{Results}

\subsection{Integral Accessibility to Gyms}

Then, the isochrones curves corresponding to the graphic representation of the integral accessibility to the different gyms in the area are presented (See Figure 3). At first glance, we can see that all the gyms are located in the central and most inhabited areas of both municipalities, there are very few establishments that provide this service in the surrounding areas. Starting with a range of 0 to 5 minutes of travel, where the distances to travel are less than 1 kilometer away and are usually in the areas surrounding the equipment; until reaching a range of 135 to 140 minutes as the maximum travel time indicator, which is only reached in the areas furthest away from the central part of the city, that is, rural areas, in which you must travel to 6.5 kilometers away to reach the closest equipment (Escobar \& Cardona, 2018).

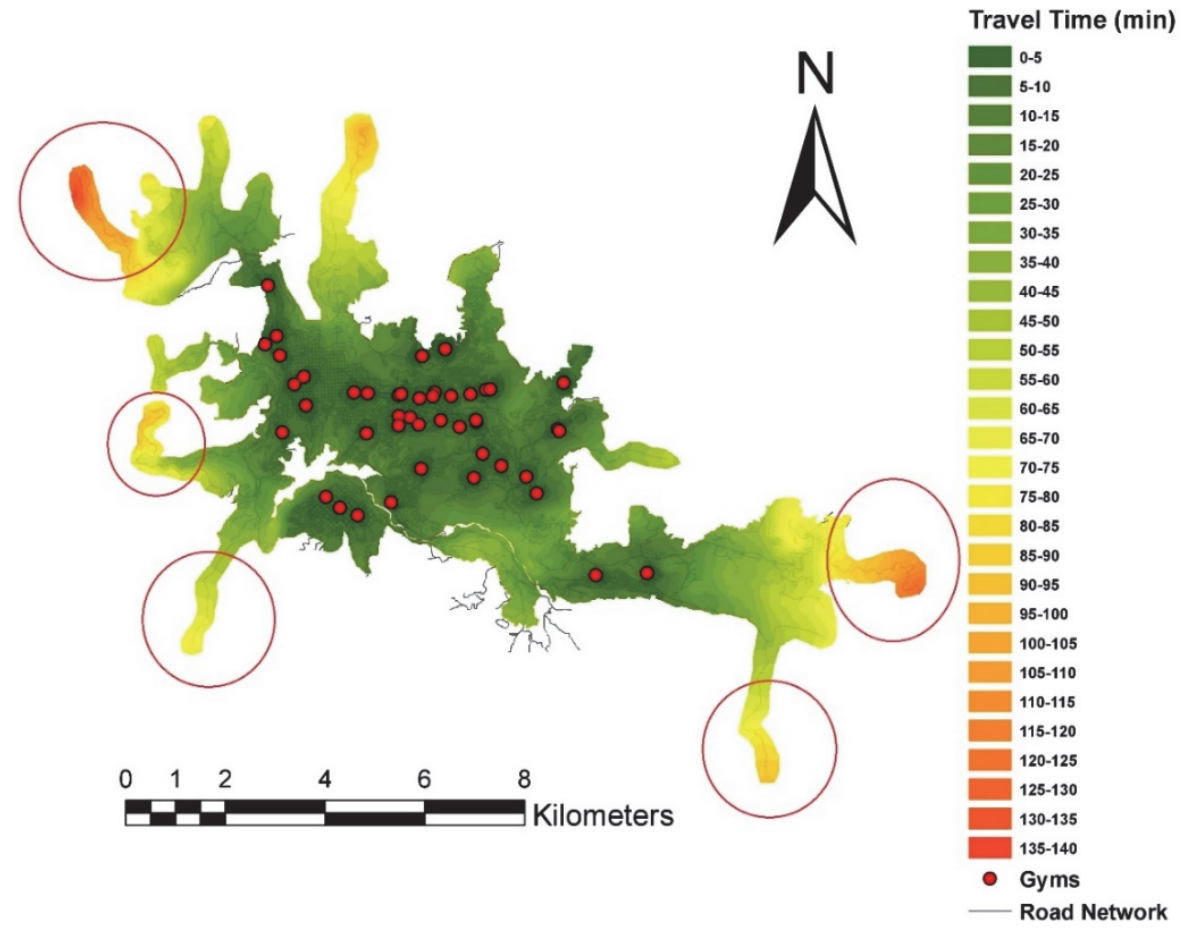

Figure 3. Accessibility to gyms

Source: Self-made.

In the central area of the city, almost entirely, it is possible to appreciate a good accessibility, which occurs when the travel time is less than 20 minutes, this makes that the walk is taken as the first transportation option (Escobar $\&$ Cardona, 2018). Contrary to this, in figure 3 there are critical zones in terms of travel time, some of them are the El Tablazo trails to the southwest of the map, El Arenillo to the west and Gallinazo to the southeast. However, the two most outstanding areas date from the path La Linda to the northwest of the map and Maltería to the east of it, since it is possible to reach the maximum travel times within the study. 


\subsection{Analysis by Population and Area of Inference}

It is necessary to evaluate the accessibility conditions based on the population and the area of inference of each equipment, comparing them with the coverage of the isochronous curves. For this, the coverage graphs, the frequency histogram and the cumulative percentage ogive are presented below (Figure 4 and 5).

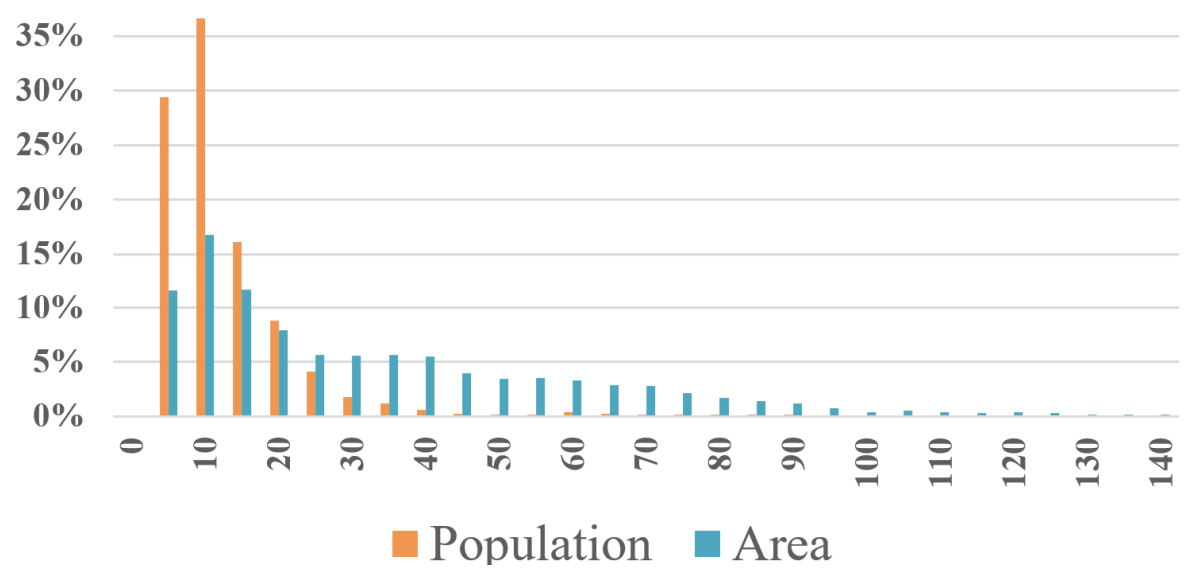

Figure 4. Histogram of coverage of area and population

Source: self-made.

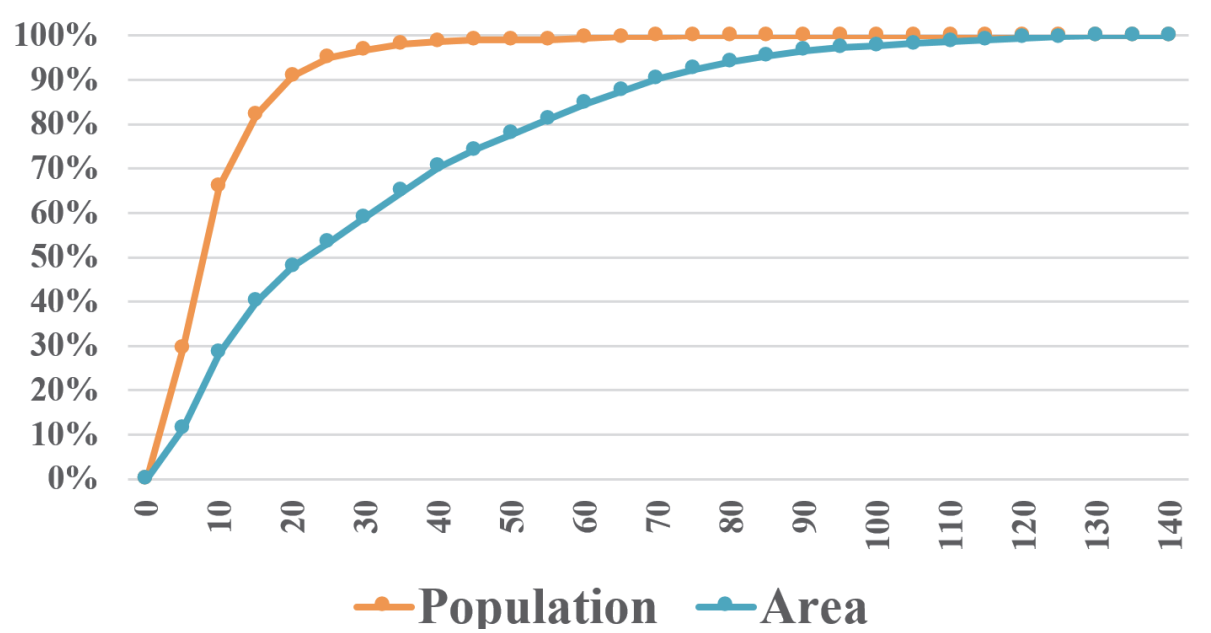

Figure 5. Ogive of accumulated percentages of coverage of area and population

Source: Self-made.

In this way, the histogram makes it clear that, despite not being a large number of establishments that provide such service, due to the small size of both municipalities, the majority of the population is covered by travel times of less than 15 minutes. More specifically, 29\% of the population, that is 123496 inhabitants, are less than 5 minutes from their nearest gym by foot; as well as $153630(37 \%)$ inhabitants are in the interval that goes from 5 to 10 minutes of travel, in order to perform such physical activity. On the other hand, it is clear that, despite not being bad, the coverage of the area with respect to the population is not the best, since up to 70 minutes of travel, there is a considerable percentage of it. The above is due to the fact that the largest areas in both municipalities are spaces that are at the ends of the region, which are practically uninhabited, which means that the population is centralized and, as a result, there are no gyms in the surrounding areas and they make travel times for the area greater than 20 or 30 minutes.

Also looking at figure 5, a trend similar to that expressed by the histogram can be seen, $91 \%$ of the population (381 464 inhabitants) is covered by travel times of less than 20 minutes, that is, less than $10 \%$ of the inhabitants of both municipalities must access a different mode of transport to the walk to reach their nearest gym.

\subsection{Analysis by Strata}


In the accumulated percentage ogive (figure 6) inequality due to social classes is evident, the difference in accessibility in each of the neighborhoods that make up each of the strata is marked with respect to those that make up strata 1 and 2. While the coverage of up to 5 minutes for strata 1 and 2 is $10 \%$ and $15 \%$ respectively, for the rest of them, they exceed $30 \%$ and reach values of up to $54 \%$. Such inequality is present in almost all the analysis, although it is undeniable that, despite not having much difference, the neighborhoods that make up stratum 2 improve their conditions as they increase travel times. Bearing in mind that 20 minutes of walking is the maximum time to prefer this means of transport (Escobar \& Cardona, 2018), at that point, while stratum 1 only covers $78 \%$ of its population, the other strata surpass $85 \%$ and up to $90 \%$ of it.

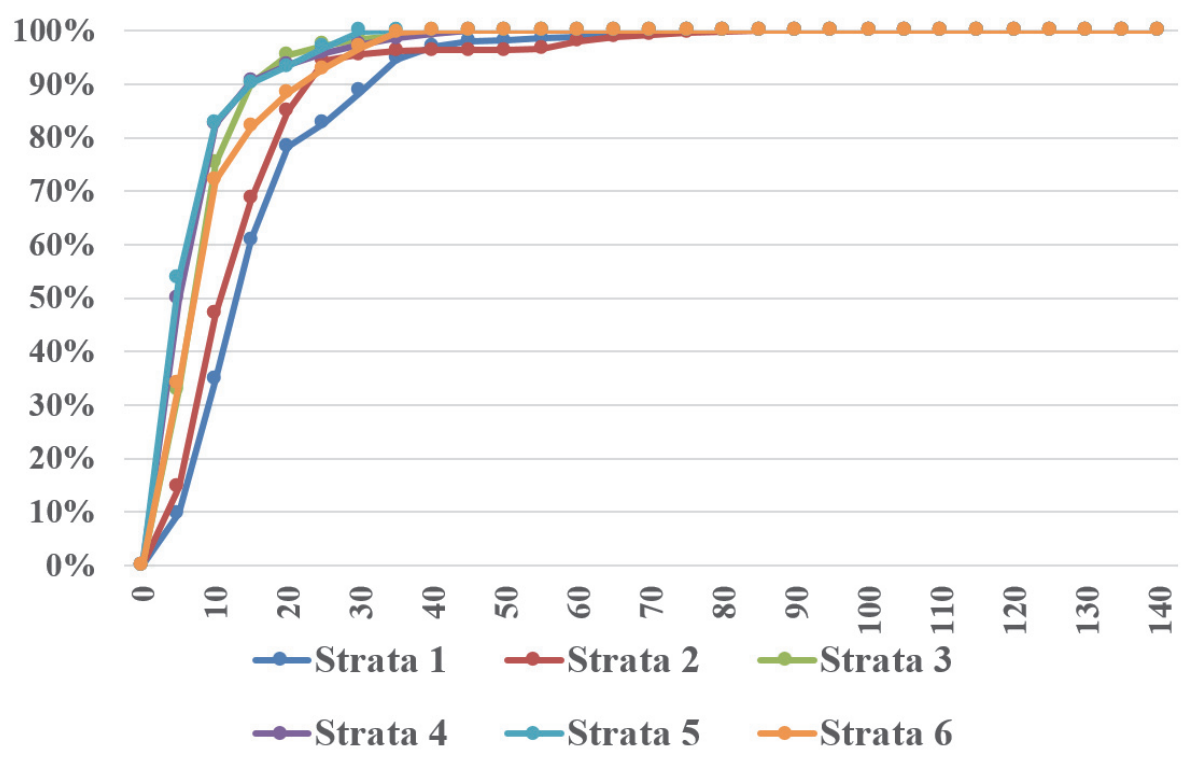

Source: Self-made.

Figure 6. Population coverage according to social strata

It is worth noting the accessibility behavior in terms of the neighborhoods that make up strata 6 , which theoretically should head the statistics, thus surpassing the rest of their peers. However, it is observed that its coverage is below strata 3,4 and 5, exceeding only strata 1 and 2, reaching $100 \%$ of its coverage only after 35 minutes of travel, time for which would no longer take the walk as a preferred means of transport. However, this phenomenon occurs because the majority of neighborhoods that make up this stratum are usually located on the frontiers of the city or have a private space for the realization of physical activity, which is why there are no established gyms close to such sectors.

\subsection{Critical Areas}

The path La Linda is inhabited by 3831 people and its area reaches 28 hectares, counting with a population density of 138 people per hectare, almost double the general value. This is a problem with regard to the subject, since from the calculations made, as mentioned above, this path is part of the most critical areas with less coverage of the city. As shown in figure 7, its population coverage is quite deficient, $100 \%$ of its inhabitants should walk at least 45 minutes to reach the nearest gym, thus being forced to take motorized means of transport, which clearly discourages the completion of said physical activity, taking into account the factors of time and money invested by people who mostly have a low socioeconomic level. There is also the case of the Maltería area, which has a special dye. This space is mostly destined to industrial production, which is evident when confirming that it has a population density of 3 people per hectare, a value much lower than that found in the city; all this to be inhabited by 611 people and own 218 hectares of land. Similar to the previously mentioned zone, all the inhabitants of Maltería must invest no less than 25 minutes of walking to reach the nearest gymnasium, as well as the coverage of $80 \%$ of its population is hardly given for times longer than 70 minutes.

\section{Conclusions}

Because of the once nascent and currently growing 'fitness' trend, as it is known around the world, the establishment of gyms or training centers according to the Chamber of Commerce increases exponentially, uncontrollably and in some cases, invasive. According to the International Health, Racquet \& Sportsclub 
Association (IHRSA), association intended, among other things, to the analysis, study, improvement and operation of the different gymnasiums in the world, as quoted by the newspaper El Colombiano (2018), for the beginning of the year 2018, Colombia had a total of 1752 gyms legally established based on the association information, being the fifth country with the largest market in Latin America, this without counting the popularly called neighborhood gyms, which operate without any legal control. In addition, in 2015, the IHRSA mentioned that the country had $1 \%$ of the established gymnasiums in the world, which is a considerable value taking into account that Colombia is inhabited by approximately $0.65 \%$ of the world population.

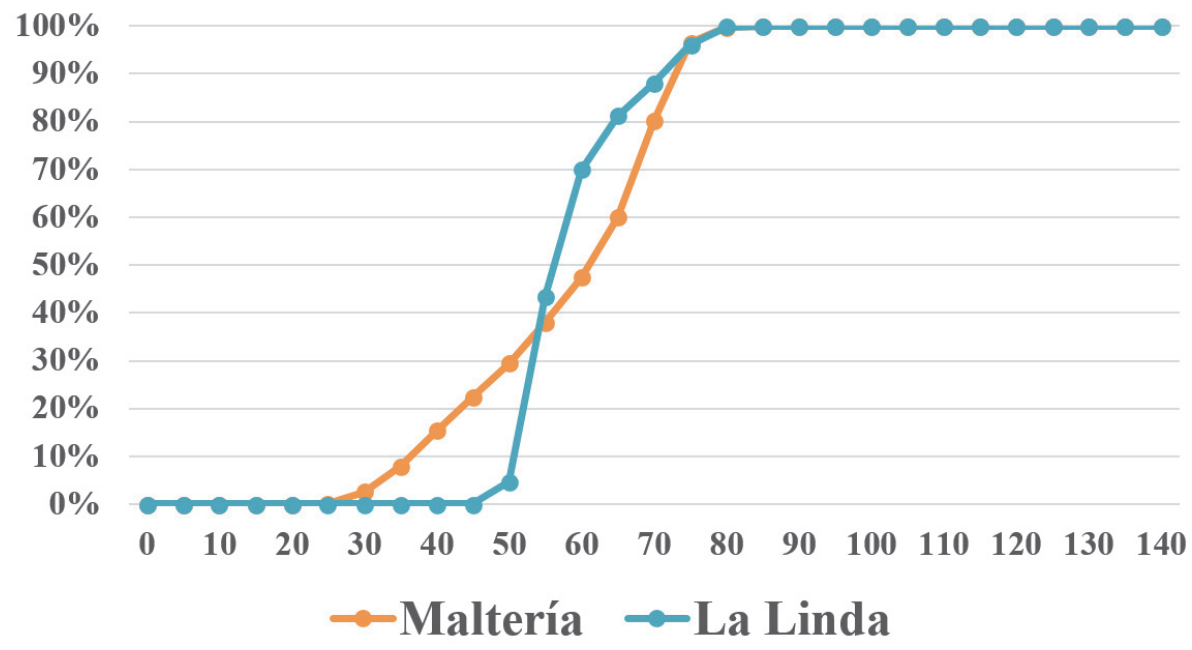

Figure 7. Coverage for inhabitants of La Linda and Maltería

Source: Self-made.

Now, if the country has such a large number of establishments, why do sedentary figures amount to $60 \%$ ? According to data provided by the Chamber of Commerce of the region, it was possible to determine that Manizales has 45 gyms distributed throughout the area, clearly concentrated in the central and urban part of the city, with which it was possible to determine that there is 1 gym for every 9300 inhabitants. As mentioned above, one of the major factors that affect the initiation and continuity of a person in a gym is the availability of time, which can be seriously affected if the city does not have good accessibility around these facilities. Through the research carried out in the municipalities of Manizales and Villamaría, it was possible to appreciate that a large part of the population has good accessibility to gyms since, for the most part, more than $90 \%$ should use less than 20 minutes to get to the nearest training center.

However, through the analysis of social strata, it was possible to determine the deficiency in accessibility for strata 1 and 2, all due to the few gyms that are located in the neighborhoods corresponding to such strata, evidencing the economic inequality since the majority of its inhabitants do not have the solvency to pay the monthly payment that these establishments charge on average. That being the case, it would not be profitable for anyone to create a gymnasium in such spaces, in spite of this, the most appropriate measure would be to open some type of gymnasium or low cost training center, to improve accessibility in those areas and putting it within reach of Its economic capacity, to encourage the practice of exercise and avoid the falling in sedentary lifestyle. Based on this principle and seeking to reduce the social gap, the City Hall of Manizales, through the Ministry of Sports, began in 2017 the installation of outdoor gyms in green areas of the city, all of them for free use and equipped with basic machines that allow the user to perform different cardiovascular and muscle-building exercises (Sal de Prensa de Manizales, 2017). In the same way, the areas that turned out to be more critical in terms of their travel times were analyzed, from which it is worth mentioning the poor accessibility of the village of La Linda, which has a large number of inhabitants and, according to data from the Chamber of Commerce, no gym near it. It is possible that such a gym exists but it is not constituted legally, since, despite not being a high stratum area, a large part of its community could be able to pay for it; therefore, it would be advisable to carry out a regularization by the governing body of the possible gyms in the area, formalizing the contractual link and strengthening the relationship with the physical activity of the inhabitants of the area and avoiding the risks derived from their lack of practice.

\section{Acknowledgments}

The authors would like to thanks to the research group in sustainable mobility of the national university of 
Colombia in Manizales.

\section{References}

Alcaldía de Manizales (2017). Plan Maestro de Movilidad de Manizales: Línea base y diagnóstico de la situación actual de la movilidad de Manizales. Manizales.

Asociación Turística Empresarial de Caldas - ATEC (2015). Inventario turistico todo sobre sus atractivos, sitios de interes y actividades.

Cámara de Comercio de Manizales por Caldas. (2018). Bases de datos de los establecimientos de comercio dedicados a la gestión de instalciones deportivas, ubicados en los municipios de Villmamría y Manizales.

Departamento Administrativo Nacional de Estadística - DANE. (2010). Proyecciones de población total por sexo y grupos de edad de 0 hasta 80 y más años $(2005$ - 2020). Retrieved from http://www.dane.gov.co/index.php/estadisticas-por-tema/demografia-y-poblacion/proyecciones-depoblacion

Departamento Administrativo Nacional de Estadistica - DANE. (2018). Estratificación Socioeconómica. Retrieved from http://www.dane.gov.co/index.php/69-espanol/geoestadistica/estratificacion/468-estratificacionsocioeconomica

Dijkstra, E. W. (1959). A note on two problems in connexion with graphs. Numerical Mathematics, 1(1), 269-271. https://doi.org/10.1007/BF01386390

El Colombiano (January 15, 2018). La importante cifra que mueven los gimnasios en Colombia. Retrieved from $\mathrm{http}: / / w w w . e l c o l o m b i a n o . c o m / n e g o c i o s / e m p r e s a s / n e g o c i o-d e-l o s-g i m n a s i o s-e n-c o l o m b i a-I Y 8010648$

Escobar, D. A., \& Garcia, F. (2012). Territorial Accessibility Analysis as a Key Variable for Diagnosis of Urban Mobility: A Case Study Manizales (Colombia). Procedia - Social and Behavioral Sciences, 48, 1385-1394. https://doi.org/10.1016/j.sbspro.2012.06.1114

Escobar, D. A., Cadena, C., \& Salas, A. (2016). Geospatial Coverage of Primary Activity Nodes. Contribution To Urban Sustainability Analysis By Use of a Regional Accessibility Study. Revista Escuela de ingenieria de Antioquia, 12(23), 13-27. https://doi.org/10.14508/reia.2015.12.23.13-27

Escobar, D. A., Cardona, S., \& Moncada, C. (2018). Global Mean Accessibility in Metropolitan Areas. Case Study: Chinchiná, Colombia. Indian, 11(21). https://doi.org/10.17485/ijst/2018/v11i21/123113

Escobar, D. A., Montoya, J. A., \& Moncada, C. A. (2018). Características de Accesibilidad geográfica de un área de patrimonio arquitectónico en Manizales - Colombia. Revista Espacios, 39(06), 8. Recuperado a partir de http://www.revistaespacios.com/a18v39n06/a18v39n06p08.pdf

Franco, A. M., Ayala, J. E., \& Ayala, C. F. (2011). La salud en los gimnasios: Una mirada desde la satisfacción personal. Revista Hacia la Promoción de la Salud.

Geurs, K. T., \& Ritsema van Eck, J. R. (2003). Evaluation of accessibility impacts of land-use scenarios: The implications of job competition, land-use, and infrastructure developments for the Netherlands. Environment and Planning B: Planning and Design, 30(1), 69-87. https://doi.org/10.1068/b12940

Giraldo, R. (2012). Introducción a la geoestadística. Universidad Nacional de Colombia, Sede Bogotá.

Gobierno de Caldas. (February 17, 2018). Comenzaron preparativos en Manizales y Caldas para recibir a cerca de 1600 deportistas que participarán en los juegos Supérate Intercolegiados 2018. Retrieved from https:/caldas.gov.co/index.php/prensa/noticias/4479-comenzaron-preparativos-en-manizales-y-caldas-pararecibir-a-cerca-de-1-600-deportistas-que-participaran-en-los-juegos-superate-intercolegiados-2018

Hansen, W. G. (1959). How Accessibility Shapes Land Use. Journal of the American Planning Association, 25(2), 73-76. https://doi.org/10.1080/01944365908978307

Ingram, D. R. (1971). The Concept of Accessibility; A search for an operational form, (June 2012), 37-41.

Kozyrev, V. P. (1972). Graph Theory, 10, 489-519.

Moncada, C., Cardona, S., \& Escobar, D. (2018). Saving Travel Time as an Urban Planning Instrument. Case Study. Modern Applied Science, 12(6), 44-57. https://doi.org/10.5539/mas.v12n6p44

Montoya, J. A., Escobar, D. A., \& Zuluaga, J. D. (2017). Acceso peatonal y cobertura de las estaciones del sistema de bicicletas públicas de la ciudad de Manizales. Revista Espacios, 2.

Morris, J. M., Dumble, P. L., \& Wigan, M. R. (1979). Accessibility indicators for transport planning. 
Transportation Research Part A: General, 13(2), 91-109. https://doi.org/10.1016/0191-2607(79)90012-8

Organización Mundial de la Salud -OMS. (2002). Informe sobre la salud en el mundo 2002: Reducir los riesgos y promover una vida sana. Organización Mundial de la Salud OPS, 175.

Organización Panamericana de la Salud - OPS. (2007). Salud en las Americas 2007 Volumen I - Regional, 482.

Retrieved

from http://www.paho.org/cor/index.php?option=com_docman\&task=doc_view\&gid=256\&Itemid=

Perilla, D. J., Escobar, D. A., \& Cardona, S. (2018). New Transportation Infrastructure Impact in Terms of Global Average Access - Intersection "La Carola " Manizales (Colombia) Case Study. Contemporary Engineering Sciences, 11(5), 215-227. http://doi.org/https://doi.org/10.12988/ces.2018.812

Prasetiyowati, S. suryani, Imrona, M., Ummah, I., \& Sibaroni, Y. (2016). Prediction of Public Transportation Occupation Based on Several Crowd Spots Using Ordinary Kriging Method. Journal of Innovative Technology and Education, 3(1), 93-104. https://doi.org/10.12988/jite.2016.6723

Press Centre Mayoralty of Manizales (November 3, 2017, 2018a). A Veinte nuevos gimnasios al aire libre tendrá Manizales. Retrieved from: http://saladeprensamanizales.com/noticia/4867

Rodríguez Díaz, V. (2011). Medición de la accesibilidad geográfica de la población a los Hospitales de Alta Resolución de Andalucía mediante herramientas SIG basadas en el análisis de redes. GeoFocus. Revista Internacional de Ciencia y Tecnología de la Información Geográfica, (11), 265-292. https://doi.org/10.1017/CBO9781107415324.004

Secretaría del Deporte Alcaldía de Manizales. (2015). Ciclovía. Retrieved from http://www.corcade.com/CICLOVIA/ciclovia.html

Varela, M. T., Duarte, C., Salazar, I. C., Lema, L. F., \& Tamayo, J. A. (2011). Actividad física y sedentarismo en jóvenes universitarios de Colombia. Colombia médica, 42, 269-277. Recuperado a partir de http://www.scielo.org.co/pdf/cm/v42n3/v42n3a2.pdf

Varo, J., Martínez, A., \& González, G. (2003). Beneficios de la actividad física y riesgos del sedentarismo. Medicina Clínica, 121(17), 665-672. https://doi.org/10.1016/S0025-7753(03)74054-8

Younes, C., Escobar, D. A., \& Holguín, J. M. (2016). Equidad, accesibilidad y transporte. Aplicación explicativa mediante un análisis de accesibilidad al sector universitario de manizales (Colombia). Informacion Tecnologica, 27(3), 107-118. https://doi.org/10.4067/S0718-07642016000300010

Zuluaga, J. D., Escobar, D. A., \& Hincapié, J. D. (2017). Calidad en la educación e infraestructuras del transporte desde la accesibilidad territorial. Departamento de Caldas en Colombia como caso de estudio. Informacion Tecnologica, 28(6), 169-180. https://doi.org/10.4067/S0718-07642017000600018

\section{Copyrights}

Copyright for this article is retained by the author(s), with first publication rights granted to the journal.

This is an open-access article distributed under the terms and conditions of the Creative Commons Attribution license (http://creativecommons.org/licenses/by/4.0/). 